\title{
Sweet Potato Tissue-Epoxy Resin Composite Biosensor for Hydroquinone Determination in Photographic Process Wastewater
}

\author{
Karina O. Lupetti, Giacomo Zanotto-Neto and Orlando Fatibello-Filho* \\ Departamento de Química, Universidade Federal de São Carlos, CP 676, 13560-970 São Carlos-SP, Brazil
}

\begin{abstract}
Um biossensor de grafite-resina epóxi-tecido de batata doce (fonte de polifenol oxidase) foi desenvolvido nesse trabalho. As composições avaliadas de grafite-resina epóxi-tecido vegetal variaram de 30 a $80 \%(\mathrm{~m} / \mathrm{m})$ de grafite, de 5 a $60 \%(\mathrm{~m} / \mathrm{m})$ de resina epóxi e de 5 a $20 \%(\mathrm{~m} / \mathrm{m})$ de tecido. Os voltamogramas de varredura cíclica e linear foram obtidos variando a velocidade de varredura de 25 a $300 \mathrm{mV} \mathrm{s}^{-1}$ em uma faixa de $\mathrm{pH}$ de 3 a 8 em tampão fosfato $0,1 \mathrm{~mol} \mathrm{~L}^{-1}$. Vários compostos fenólicos foram determinados utilizando o biossensor proposto e hidroquinona foi determinada em águas residuárias de processo fotográfico. Desvios padrão relativos de $0,7 \%$ e $3,3 \%$ foram obtidos empregando o mesmo biocompósito $(n=10)$ e três diferentes biossensores construídos $(n=3)$, respectivamente. Sensibilidade e seletividade foram avaliadas empregando o biossensor para hidroquinona com um tempo de vida superior a 6 meses (mais de 500 determinações).
\end{abstract}

A biosensor of graphite-epoxy resin-sweet potato tissue (source of polyphenol oxidase) was developed in this work. The evaluated compositions of graphite-epoxy resin-vegetable tissue were varied from 30 to $80 \%(\mathrm{~m} / \mathrm{m})$ graphite; from 5 to $60 \%(\mathrm{~m} / \mathrm{m})$ epoxy resin and from 5 to $20 \%(\mathrm{~m} / \mathrm{m})$ tissue. The cyclic and linear sweep voltammograms were obtained at a scan rate between 25 and $300 \mathrm{mV} \mathrm{s}^{-1}$ in the $\mathrm{pH}$ range from 3 to 8 in $0.1 \mathrm{~mol} \mathrm{~L}^{-1}$ phosphate buffer solutions. Several phenolic compounds were determined by the proposed biosensor and hydroquinone was determined in wastewater from photographic process. Relative standard deviations of $0.7 \%$ and $3.3 \%$ were obtained employing the same biosensor $(n=10)$ and three different biosensors $(n=10)$, respectively. Sensitivity and selectivity were evaluated employing the biosensor for hydroquinone with a lifetime of at least 6 months (more than 500 determinations).

Keywords: composite biosensor, hydroquinone, sweet potato tissue, wastewater

\section{Introduction}

Nowadays, composite biosensors are efficiently used in different kinds of analytical determinations for several electroactive species, showing robustness and sensitivity. Several materials have been used to construct electrodes. Among them, carbon-based matrices are the most applied due to their high conductivity, whereas epoxy resins, silicone, polyurethane, metacrylate resin, Teflon, etc, can be employed as agglutinating agents (insulator materials). Graphite and epoxy resins are employed to construct rigid composites that can be used in aqueous or nonaqueous media, ${ }^{1}$ so the great advantage of graphite epoxy electrodes over carbon paste electrodes is their tolerance to organic solvents. This type of composite biosensor offers additional important advantages:

*e-mail: bello@dq.ufscar.br it can be customized easily according to biocatalytical and/ or electrochemical requirements; it presents low background currents, favoring a high signal-to-noise ratio, and lower detection limits and it offers a new active layer after removal of the outer surface, extending the lifetime of such electrodes. ${ }^{2}$

Vegetable tissues have been employed as source of several enzymes, among them, polyphenol oxidase (PPO) and peroxidase $^{3,4}$ are applied to modify efficiently carbon paste electrodes for different kinds of analytes, mainly phenolic compounds. A review focusing the utility of vegetable tissue and crude extracts can be found in the literature. ${ }^{5}$

Hydroquinone is a phenolic compound that is important in a wide number of biological, cosmetic and industrial processes (dermatological cream, coal-tar production, paper manufacturing or in photographic developing). In the aquatic environment, it is considered an important xenobiotic micropollutant. Thus, hydroquinone and its reaction products 
have been determined by several analytical techniques in cosmetics, hair products and pharmaceutical preparations, in air samples and in different biological fluids due to its possible carcinogenic effect. The determination and quantification of this analyte may be done using different techniques, such as HPLC $^{6,7}$ with different detectors, flow injection analysis, ${ }^{8}$ kinetic spectrophotometry, ${ }^{9,10}$ GC/MS, ${ }^{11,12}$ differential pulse voltammetry, ${ }^{13}$ the Belousov-Zhabotinski oscillating chemical reaction in a continuous-flow stirredtank reactor ${ }^{14,15}$ or with biosensors. ${ }^{16,17}$ The detection limits found in the literature for hydroquinone vary in a wide range of concentrations depending on the technique used, the lowest limits are obtained by using electrochemical detection systems. Fang et al..$^{18}$ describe a system of analysis by flow injection with amperometric detection that reaches a detection limit of $22 \mu \mathrm{g} \mathrm{L} \mathrm{L}^{-1}$ for hydroquinone. This limit descends to $0.05 \mu \mathrm{g} \mathrm{L}^{-1}$ with capillary electrophoresis or liquid chromatography with electrochemical detection.

There are several works ${ }^{19-23}$ describing the application of vegetable tissues as the source of PPO in different determination systems for phenolic compounds and catecholamines. Nevertheless, mainly pharmacological compounds were determined employing these materials. In addition, only carbon paste $^{23}$ or Clark type ${ }^{24}$ electrodes have been reported as the basis for this type of enzymatic modification. The use of epoxy resin and graphite powder improves some characteristics of the sensor for the determination of phenolic compounds that are environmentally damaging.

In the present work, a suitable composite biosensor of sweet potato tissue- graphite-epoxy resin was developed for hydroquinone determination in photographic process wastewater.

\section{Experimental}

\section{Apparatus}

A knife-grinder from Tecnal TE 631 was employed to grind the dried sweet potato tissue into small particles and mesh sieves (Granutest) were used to select different particle sizes $(0.106 ; 0.250 ; 0.350 ; 0.500 \mathrm{~mm})$ for the composite biosensor construction.

All electrochemical experiments were carried out in a $15 \mathrm{~mL}$ thermostated glass cell at $25^{\circ} \mathrm{C}$. A three electrodes assembly incorporating the biosensor as working electrode; an $\mathrm{Ag} / \mathrm{AgCl}\left(3.0 \mathrm{~mol} \mathrm{~L}^{-1} \mathrm{KCl}\right)$ reference and platinum auxiliary electrodes were used in all experiments. Cyclic voltammetry (CV) and linear sweep voltammetry (LSV) measurements were performed with an EG \& G PAR, Model 273 A Potentiostat/Galvanostat analyzer controlled by a GPIB PCIIA interfacial program.

\section{Reagents}

All chemicals were of analytical-reagents grade and all solutions were prepared with water from a Millipore (Bedford, MA, USA) Milli-Q system (Model UV Plus Ultra-Low Organic Water).

The composite biosensor was prepared using an Acheson 38 graphite powder from Fisher, epoxy resin from Reforplás and PPO from sweet potato tissue. Healthy sweet potato (Ipomoea batatas Lam (L.)) was purchased from a local producer.

All phenolic compounds, such as catechol, hydroquinone, chloromethylphenol, 4-nitrophenol, 4-chlorophenol and phenol were purchased from Aldrich and $2.5 \times 10^{-2} \mathrm{~mol} \mathrm{~L}^{-1}$ stock solutions were prepared in $0.1 \mathrm{~mol}$ $\mathrm{L}^{-1}$ phosphate buffer solution at $\mathrm{pH}$ 7.0.

Hydroquinone's wastewater samples were obtained from a local photographic shop.

\section{Biosensor preparation}

The bicomposite was initially prepared by homogenizing the mass varying from 0.150 to $0.400 \mathrm{~g}$ of graphite powder and a specific mass $(0.025 \mathrm{~g} ; 0.050 \mathrm{~g} ; 0.075 \mathrm{~g}$ and $0.100 \mathrm{~g})$ of sweet potato tissue in a mortar for at least $20 \mathrm{~min}$. After that, 0.025 to $0.300 \mathrm{~g}$ of epoxy resin was subsequently added to this mixture in a mortar and mixed for at least $20 \mathrm{~min}$ to produce the final biocomposite, that was packed $(330 \mathrm{mg})$ into the tip of a $1 \mathrm{~mL}$ insulin plastic syringe and a copper wire was used to provide the external electric contact.

\section{Voltammetric measurements}

Cyclic and linear sweep voltammetry measurements were performed in an unstirred and non-aerated $0.1 \mathrm{~mol}$ $\mathrm{L}^{-1}$ phosphate buffer solution at $\mathrm{pH} 7.0$ and $25^{\circ} \mathrm{C}$. The cyclic voltammograms were obtained by cycling the potential from 1.0 to $-1.0 \mathrm{~V}$ vs. $\mathrm{Ag} / \mathrm{AgCl}\left(3.0 \mathrm{~mol} \mathrm{~L}^{-1}\right.$ $\mathrm{KCl})$ reference electrode at a scan rate of $200 \mathrm{mV} \mathrm{s}^{-1}$, after successive additions of phenolic compounds or sample solutions. The linear sweep voltammograms were performed between 0.25 and $-0.55 \mathrm{~V}$ vs. $\mathrm{Ag} / \mathrm{AgCl}$ at a scan rate of $200 \mathrm{mV} \mathrm{s}^{-1}$.

\section{Optimization of the biosensor response}

Intending to achieve the best composition for the proposed composite biosensor some studies were performed. The composite biosensor response for $0.025 \mathrm{~mol} \mathrm{~L}^{-1}$ catechol solution in $0.1 \mathrm{~mol} \mathrm{~L}^{-1}$ phosphate buffer solution at $\mathrm{pH} 7.0$ was initially studied for compositions varying from 30 to 
$80 \%(\mathrm{~m} / \mathrm{m})$ of graphite powder, from 5 to $60 \%(\mathrm{~m} / \mathrm{m})$ epoxy resin, and from 5 to $20 \%(\mathrm{~m} / \mathrm{m})$ vegetable tissue. Also, the effect of particle sizes of the dried sweet potato tissue was evaluated in the range from $0.106 \mathrm{~mm}$ to $0.500 \mathrm{~mm}$.

The $\mathrm{pH}$ was varied from 3.0 to 8.0 and the effect on the composite biosensor response for $4.5 \times 10^{-4} \mathrm{~mol} \mathrm{~L}^{-1}$ catechol solution was also investigated.

Initial stirring time varying from 30 to $150 \mathrm{~s}$ and scan rate from 25 to $300 \mathrm{mV} \mathrm{s}^{-1}$ have been also studied, employing the same catechol solution used for $\mathrm{pH}$ studies.

\section{Recovery and repeatability studies}

Aiming to evaluate the recovery, $4.95 \times 10^{-4}, 9.80 \times 10^{-4}$ and $1.45 \times 10^{-3} \mathrm{~mol} \mathrm{~L}^{-1}$ of hydroquinone were added to the sample of wastewater from three photographic process and the cathodic peak current was registered. In order to estimate the repeatability, ten reference solutions of $5.0 \times 10^{-4} \mathrm{~mol} \mathrm{~L}^{-1}$ hydroquinone were measured in $0.1 \mathrm{~mol}$ $\mathrm{L}^{-1}$ phosphate buffer solution at $\mathrm{pH}$ 7.0.

\section{Linearity and relative response studies}

After the optimization studies, an analytical curve was plotted using the developed composite biosensor for hydroquinone solutions in the following concentrations: $2.5 \times 10^{-4}, 7.4 \times 10^{-4}, 1.2 \times 10^{-3}, 1.7 \times 10^{-3}, 2.1 \times 10^{-3}, 3.0 \times 10^{-3}$ and $3.9 \times 10^{-3} \mathrm{~mol} \mathrm{~L}^{-1}$.

Several phenolic compounds were determined by the proposed methodology, among them: catechol; hydroquinone; chloromethylphenol; 4-nitrophenol; 4-chlorophenol and phenol and a relative response relationship were obtained for this composite biosensor.

\section{Hydroquinone determination and comparative method}

Hydroquinone was chosen to be determined in wastewater from photographic process by the standard addition procedure, using linear sweep voltammetry measurements due to the sensibility of this technique, considering the analyte concentration in the samples.

A comparative methodology employing the redox titration of the analyte with $0.05 \mathrm{~mol} \mathrm{~L}^{-1} \mathrm{Ce}^{4+}$ solution was performed to determine the hydroquinone concentration in the samples. ${ }^{25}$

\section{Results and Discussion}

The robustness and sensitivity are the most interesting characteristics of this kind of biosensor for phenolic compounds determination. Figure 1 presents the difference in the $\mathrm{CV}$ response between a plain carbon paste electrode and the proposed biosensor. In this study, cyclic voltammetric measurements were performed scanning the potential between 1.0 and $-1.0 \mathrm{~V}$ vs. $\mathrm{Ag} / \mathrm{AgCl}$ at a scan rate of $200 \mathrm{mV} \mathrm{s}^{-1}$ using both electrodes. The cyclic voltammograms $\mathrm{A}$ and $\mathrm{C}$ were obtained using both electrodes in $0.1 \mathrm{~mol} \mathrm{~L}^{-1}$ phosphate buffer solution, respectively. The cyclic voltammograms B and D were obtained using the plain carbon paste and the biosensor in a $2.34 \times 10^{-3} \mathrm{~mol} \mathrm{~L}^{-1}$ catechol solution, respectively. As can be seen, the composite biosensor presents higher signal (higher cathodic current at $-0.20 \mathrm{~V}$ ) than the plain carbon paste in the presence of catechol solution.

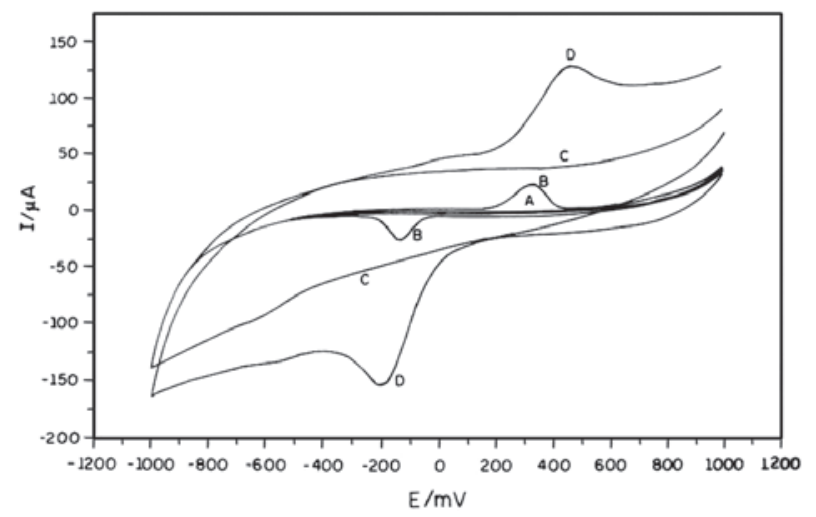

Figure 1. Cyclic voltammograms obtained using the plain electrode (A) and the biosensor (C) in $0.1 \mathrm{~mol} \mathrm{~L}^{-1}$ phosphate buffer solution at $\mathrm{pH} 7.0$ and the plain electrode (B) and the composite biosensor (D) in $2.34 \times 10^{-3}$ catechol solution, at $200 \mathrm{mV} \mathrm{s}^{-1}$ scan rate.

\section{Composite biosensor optimization}

To obtain the highest signal to noise ratio for the composite biosensor with polyphenol oxidase, the effects of several variables were evaluated employing the proposed device. Table 1 summarizes the range over each variable was studied and the optimal value found in those studies.

The effect of graphite powder varying from 30 to $80 \%$ $(\mathrm{m} / \mathrm{m})$, epoxy resin from 5 to $60 \%(\mathrm{~m} / \mathrm{m})$, and tissue from 5 to $20 \%(\mathrm{~m} / \mathrm{m})$ on the biosensor response using $0.025 \mathrm{~mol}$ $\mathrm{L}^{-1}$ catechol solution at $\mathrm{pH} 7$ was studied. The best composition obtained was $75: 15: 10 \%(\mathrm{~m} / \mathrm{m})$ graphite: vegetable tissue: epoxy resin, respectively. Besides, the diameter of the vegetable tissue particles was evaluated in the range from $0.106 \mathrm{~mm}$ to $0.500 \mathrm{~mm}$ and the higher signal to noise ratio was obtained with $0.350 \mathrm{~mm}$ particles size.

The highest signal for phenolic compounds was found at $\mathrm{pH}$ 7. In this study, a scan rate of $200 \mathrm{mV} \mathrm{s}^{-1}$ was chosen to achieve a higher cathodic peak current at $-0.25 \mathrm{~V}$. In addition, the effect of initial stirring time in an interval 
Table 1. Optimization of composite biosensor parameters

\begin{tabular}{lcc}
\hline Parameters & $\begin{array}{c}\text { Range } \\
\text { studied }\end{array}$ & $\begin{array}{c}\text { Optimal } \\
\text { value }\end{array}$ \\
\hline Graphite powder / \% (m/m) & $30-80$ & 75 \\
Epoxy resin / \% $(\mathrm{m} / \mathrm{m})$ & $5-60$ & 10 \\
Vegetable tissue / \% (m/m) & $5-20$ & 15 \\
Vegetable tissue grain diameter / mm & $0.106-0500$ & 0.350 \\
$\mathrm{pH}$ & $3.0-8.0$ & 7.0 \\
Scan rate / $\left(\mathrm{mV} \mathrm{s}^{-1}\right)$ & $25-300$ & 200 \\
Potential range / V (CV for catechol) & 1.0 to -1.0 & -0.20 \\
Potential range / V (LSV for hydroquinone) & 0.20 to -0.50 & -0.25 \\
\hline
\end{tabular}

from 30 to $150 \mathrm{~s}$ on the biosensor, for $5.0 \times 10^{-4} \mathrm{~mol} \mathrm{~L}^{-1}$ hydroquinone in $0.1 \mathrm{~mol} \mathrm{~L}^{-1}$ phosphate buffer solution at $\mathrm{pH} 7.0$, was investigated. It was observed that $120 \mathrm{~s}$ was the best initial stirring time to determine this substrate.

\section{Recovery and repeatability studies}

Recoveries studies of $4.95 \times 10^{-4}, 9.80 \times 10^{-4}$ and $1.45 \times 10^{-3} \mathrm{~mol} \mathrm{~L}^{-1}$ of hydroquinone from 3 samples of a photographic process wastewater varied from 96.8 to $103 \%$ (Table 2) using the composite biosensor, suggesting that there are not matrix effects in hydroquinone determination.

Table 2. Results of the addition-recovery experiments using hydroquinone with three different standard concentrations

\begin{tabular}{lccc}
\hline Sample & $\begin{array}{c}\text { Hydroquinone / } \\
\text { Added }\end{array}$ & $\begin{array}{c}\left(10^{-4} \mathrm{~mol} \mathrm{~L}^{-1}\right) \\
\text { Found }\end{array}$ & Recovery / \% \\
\hline A & 4.95 & 4.79 & 96.8 \\
& 9.80 & 9.52 & 97.1 \\
& 14.5 & 14.7 & 101 \\
B & 4.95 & 4.89 & 98.8 \\
& 9.80 & 9.73 & 99.3 \\
& 14.5 & 14.6 & 101 \\
C & 4.95 & 5.12 & 103 \\
& 9.80 & 1.00 & 102 \\
& 14.5 & 14.2 & 97.9 \\
\hline
\end{tabular}

After 10 additions of $5.00 \times 10^{-4} \mathrm{~mol} \mathrm{~L}^{-1}$ hydroquinone in $0.1 \mathrm{~mol} \mathrm{~L}^{-1}$ phosphate buffer solution $(\mathrm{pH} \mathrm{7.0)}$ ) a relative standard deviation of $0.7 \%$ was obtained and the reproducibility studies between three composite biosensors showed only a slight variation of $3.3 \%$.

\section{Analytical characteristics and sample determination}

The electrochemical process involves a chemical oxidation of hydroquinone to quinone promoted by the PPO enzyme and an electrochemical reverse reaction at $-0.25 \mathrm{~V}$.
The epoxy resin was used as the agglutinant agent to provide higher mechanical resistance to the electrode in basic and acidic media.

The optimum conditions established before, namely, the composite biosensor composition of $75: 15: 10 \%(\mathrm{~m} / \mathrm{m})$ of graphite: vegetable tissue: epoxy resin, $200 \mathrm{mV} \mathrm{s}^{-1}$ scan rate, $120 \mathrm{~s}$ of initial stirring time in $0.1 \mathrm{~mol} \mathrm{~L}^{-1}$ phosphate buffer solution at $\mathrm{pH} 7.0$, were employed in the remaining determinations. Figure 2 shows the linear sweep voltammograms obtained with this composite biosensor using cathodic sweeping for: (A) $0.1 \mathrm{~mol} \mathrm{~L}^{-1}$ phosphate buffer solution, and for hydroquinone solutions at the following concentrations (B) $2.5 \times 10^{-4}$, (C) $7.4 \times 10^{-4}$, (D) $1.2 \times 10^{-3}$, (E) $1.7 \times 10^{-3}$, (F) $2.1 \times 10^{-3}$, (G) $3.0 \times 10^{-3}$ and (H) $3.9 \times 10^{-3} \mathrm{~mol} \mathrm{~L}^{-1}$. The analytical curve obtained was rectilinear from $2.5 \times 10^{-4}$ to $4.0 \times 10^{-3} \mathrm{~mol} \mathrm{~L}^{-1}$ of hydroquinone $(\mathrm{Ipc}=5.72+56883.6$ [hydroquinone]); $\mathrm{r}=0.9982$, where Ipc is the cathodic peak current in $\mathrm{mA}$ and [hydroquinone] is the hydroquinone concentration in mol L $\mathrm{L}^{-1}$, with a detection limit (three times the blank standard deviation/slope) of $3.8 \times 10^{-5} \mathrm{~mol} \mathrm{~L}^{-1}$ hydroquinone.

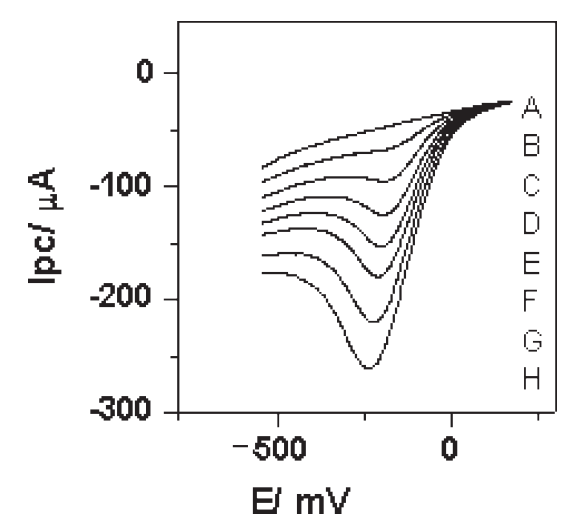

Figure 2. Linear sweep voltammograms for the construction of an analytical curve, obtained using the composite biosensor $75: 15: 10 \%(\mathrm{~m} / \mathrm{m})$ graphite:tissue:resin for (A) $0.1 \mathrm{~mol} \mathrm{~L}^{-1}$ phosphate buffer, $\mathrm{pH} 7.0$; (B) $2.5 \times 10^{-4}$; (C) $7.4 \times 10^{-4}$; (D) $1.2 \times 10^{-3}$; (E) $1.7 \times 10^{-3}$; (F) $2.1 \times 10^{-3}$; (G) $3.0 \times 10^{-3}$ and $(\mathrm{H}) 3.9 \times 10^{-3} \mathrm{~mol} \mathrm{~L}^{-1}$ hydroquinone solutions, at $200 \mathrm{mV} \mathrm{s}^{-1}$ scan rate.

Table 3 shows the relative response relationship of the composite biosensor to catechol, hydroquinone, chloromethylphenol, 4-chlorophenol, 4-nitrophenol and phenol. The electrode was more sensitive to catechol $(100 \%)$ and hydroquinone (58\%), followed by chloromethylphenol (24\%) and 4-chlorophenol (16\%), presenting no answer to 4-nitrophenol and phenol. The different responses between those phenolic compounds are due to the different substituent groups and their position. Therefore, higher signals were obtained to $-\mathrm{OH}$ groups in -ortho and -para position once they confer a higher reactivity characteristic to the compounds. 
Table 3. Relative response for different phenolic compounds

\begin{tabular}{ll}
\hline Phenolic compound & Relative response \\
\hline catechol & 100 \\
hydroquinone & 58 \\
chloromethylphenol & 24 \\
4-chlorophenol & 16 \\
4-nitrophenol & - \\
phenol & - \\
\hline
\end{tabular}

The proposed method was applied to the determination of hydroquinone in wastewater samples from photographic process. Table 4 presents the comparison between the values obtained using the proposed biosensor and a comparative method. ${ }^{25}$

Table 4. Determination of hydroquinone in wastewater samples from photographic process using a redox titration method ${ }^{25}$ and the proposed biosensor

\begin{tabular}{lccc}
\hline Sample & $\begin{array}{c}\text { Concentration of hydroquinone } \\
\text { Redox } \\
\text { titration / } \\
\left(\mathrm{mmol} \mathrm{L}^{-1}\right)\end{array}$ & $\begin{array}{c}\text { Composite } \\
\text { biosensor / } \\
\left(\mathrm{mmol} \mathrm{L}^{-1}\right)\end{array}$ & $\begin{array}{c}\text { Relative } \\
\text { error / \% }\end{array}$ \\
\hline A & 0.492 & 0.480 & -2.4 \\
B & 0.503 & 0.520 & +3.3 \\
C & 0.505 & 0.510 & +1.0 \\
\hline
\end{tabular}

$\mathrm{n}=5$; confidence level of $95 \%$.

The lifetime of this composite biosensor was at least 6 months performing 500 determinations with a decreasing of $30 \%$ of the initial activity. The initial activity can be reestablished by renewing the surface and keeping under refrigeration $\left(4^{\circ} \mathrm{C}\right)$ after use.

\section{Conclusions}

The developed composite biosensor based on graphiteepoxy resin modified with PPO from sweet potato tissue was easily assembled and could be reliably used to determine hydroquinone in wastewater from photographic process samples. The robustness and sensitivity is a remarkable characteristic of this sensor. The results of the proposed method agreed at the $95 \%$ confidence level with those from a titration procedure.

\section{Acknowledgments}

Financial supports from FAPESP, CNPq and CAPES and scholarship granted by FAPESP to KOL (00/115122) are gratefully acknowledged.

\section{References}

1. Serra, B.; Jiménez, S.; Mena, M. L.; Reviejo, A. J.; Pingarrón, J. M.; Biosens. Bioelectronic 2002, 17, 217.

2. Önnerfjord, P.; Emnéus, J.; Marko-Varga, G.; Lo Gorton, G.; Biosens. Bioeletronics 1995, 10, 607.

3. Fatibello-Filho, O.; Lupetti, K. O.; Vieira, I. C.; Talanta 2001, 55, 685.

4. Vieira, I. C.; Lupetti, K. O.; Fatibello-Filho, O.; Anal. Lett. 2002, 35, 2221.

5. Fatibello-Filho, O.; Vieira, I. C.; Quim. Nova 2002, 25, 455.

6. Penner, N. A.; Nesterenko, P. N.; Analyst 2000, 125, 1249.

7. Penner, N. A.; Nesterenko, P. N.; Rybalko, N. A.; J. Anal. Chem. 2001, 56, 934.

8. Chen, G. N.; Liu, J. S.; Duan, J. P.; Chen, H. Q.; Talanta 2000 , 53,651 .

9. Afkhami, A.; Khatami, H. A.; J. Anal. Chem. 2001, 56, 429.

10. Medien, H. A. A.; Zahran, A. A.; Spectrochim. Acta, Part A 2001, 57, 2505.

11. MolnarPerl, I.; Tisza, S.; Koros, E.; KurinCsorgei, K. I.; Szalai, H. R. C.; J. High Resolut. Chromatogr. 1995, 18, 749.

12. Pryor,W. A.; Stone, K.; Zang, L. Y.; Bermúdez, E.; Chem. Res. Toxicol. 1998, 11, 441.

13. Carvalho, R. M.; Mello, C.; Kubota, L. T.; Anal. Chim. Acta 2000, 420, 109.

14. Toledo, R.; Silva, M.; Khavrus, V. O.; Strizhak, P. E.; Analyst 2000, 125, 2118.

15. Gao, J. Z.; Ren, J.; Yang, W.; Liu, X. H.; Yang, H.; Li, Q. Z.; Deng, H. L.; J. Elelectroanal. Chem. 2002, 520, 157.

16. Fatibello-Filho, O.; Vieira, I.C.; Fresenius J. Anal. Chem. 2000, $368,338$.

17. Vieira, I. C.; Fatibello-Filho, O.; Talanta 2000, 52, 681.

18. Fang, T.; Mc Grant, M.; Diamond, D.; Smyth, M. R.; Anal. Chim. Acta 1995, 305, 347.

19. Wang, Z. P.; Zhang, Z. J.; Fu, Z. F.; Fang, L. Q.; Luo, W. F.; Chen, D. L.; Zhang, X.; Anal. Chim. Acta 2003, 494, 63.

20. Lima, A. W. O.; Bora, P. S.; Ritcher, E. M.; Angnes, L.; J. Food Biochem. 2003, 27, 237.

21. Li, B. X.; Zhang, Z. J.; Jin, Y.; Biosens. Biolelectron. 2002, 17, 585.

22. Forzani, E. S.; Rivas, G. A.; Solis, V. M.; J. Electroanal. Chem. 1997, 435, 77.

23. Botre, F.; Mazzei, F.; Lanzi, M.; Lorenti, G.; Botre, C.; Anal. Chim. Acta 1991, 255, 59.

24. Eggins, B. Biosensors: An introduction, Wiley \& Teubner: New York, 1996.

25. Berka, A.; Chem. Listy 1969, 63, 298.

Received: March 14, 2006 Published on the web: September 26, 2006 